http://jmscr.igmpublication.org/home/ ISSN (e)-2347-176x ISSN (p) 2455-0450

crossref DOI: https://dx.doi.org/10.18535/jmscr/v8i3.56

\title{
Screening for Nipah virus at POC testing facility during 2019 outbreak in Kerala
}

Authors

\section{Dr Neethu John ${ }^{1}$, Dr Tanya Tonny Mampilly, Dr Chris Mary Antony, Dr Kiran T Jose, Dr Ria Catherine Vincent, Dr Anu Mary Antony, Dr J.Lancy* \\ ${ }^{1}$ Assistant Professor, GMC, Ernakulam \\ *Corresponding Author \\ Dr J.Lancy \\ Professor, GMC, Ernakulam, India}

\begin{abstract}
Nipah virus outbreak was first reported from Kerala in May 2018.By the end of May 2019, a 21 year old male patient from a village in Ernakulam district with symptoms suggestive of Nipah virus infection was admitted in a corporate hospital at Ernakulam. His blood sample was sent to NIV, Pune and the report confirmed the clinical diagnosis. Due to the difficulties encountered with transportation and subsequent delay in receiving the reports, Nipah POC testing facility was set up in the department of Microbiology, Government medical college, Ernakulam. A total number of 190 samples received from 52 patients from various districts all over Kerala were tested for Nipah virus from 6/6/2019 to 2/7/19. All samples were negative except the repeat sample received from the index case. Kerala state has an efficient health care system. Because of the combined efforts of the Department of Health Services, Health Education and Health and Family Welfare department of the state Government, Nipah outbreak was stopped with the index case.

Keywords: Nipah virus, Real time -PCR, Nipah IgM ELISA.
\end{abstract}

\section{Introduction}

Nipah virus is an RNA virus belongs to the family of Paramyxoviridae. It is a human and animal pathogen. The disease starts with upper respiratory symptoms and rapidly progresses to encephalitis. Case fatality rate is $>70 \%$. Source of infection being the secretions of fruit bats. Direct contact from one person to another leads to outbreak of Nipah virus infection.

Materials and Methods

Study Design: Cross sectional study
Study Setting: Department of Microbiology and Department of Medicine, GMC, Ernakulam

Study Period: June 2019 to August 2019 (3 months)

Study Population: Clinically suspected cases of Nipah virus infection

Specimen Collection, Transport and Processing Different types of samples such as blood, CSF, Throat swab etc. depending on the clinical features were collected from the patients under strict aseptic precautions. 


\section{Collection of Blood Sample}

$5 \mathrm{ml}$ of blood was collected after venepuncture under strict aseptic precautions. Samples were collected from patients admitted in the isolation units after wearing PPE. Samples were transported to the centre in triple packing and kept in ice packs immediately after collection.

\section{Collection of CSF sample}

After wearing PPE, $2 \mathrm{ml}$ of the CSF sample was collected by doing lumbar puncture by the physician under strict aseptic precautions.

\section{Collection of throat swab}

The patient was asked to sit comfortably on a chair and asked to open the mouth just like looking for gag reflex. After introducing a tongue depressor, the sterile swab was wiped over the proximal part of the pharynx to collect the specimen.

\section{Collection of endotracheal aspirate}

Under aseptic precautions, an endotracheal tube was introduced and aspirate was collected. At least $5 \mathrm{ml}$ of sample was collected.

\section{Collection of urine samples}

In ambulant patients after giving instructions about sample collection, $5 \mathrm{ml}$ of mid-stream urine sample was collected. From patients on indwelling catheter, $5 \mathrm{ml}$ of urine sample was collected from the tube after clamping the catheter on either sides leaving a distance of about $20 \mathrm{~cm}$ and $2 \mathrm{ml}$ of urine sample was collected using a sterile syringe and needle and transferred into a sterile screw capped plastic container.

\section{Transport of specimens}

Immediately after collection, the throat swab was put into a sterile screw capped container having Viral Transport Medium (VTM) and triple packing was done. In case of blood, urine and ET aspirate, after collecting the samples, triple packing was done and transported as such in a thermocol box tightly packed with ice packs.

During the initial phase, 21 samples were sent to National Institute of Virology (NIV), Pune.From $6 / 6 / 2019$ onwards, samples were received in the Nipah Point of care (POC) testing facility in the Department of Microbiology at GMC, Ernakulam.

\section{Processing of samples}

Samples received from various districts in the Kerala state were processed carefully inside the biosafety cabinet level 2.Opening the containers, handling the specimens, were done with meticulous care after wearing PPE. RNA separation was done first followed by detection of Nipah virus RNA by using True NaT. Temporary lab was set up by the technical experts from NIV, Pune with the available infrastructure and the tests were done by them in the beginning. On $12 / 6 / 2019$, a training programme was conducted and all the faculties, PG's and lab technicians were trained on the testing procedure. From $14 / 6 / 2019$ to $2 / 7 / 2019$, the samples were processed and tested by the faculty and lab technicians of the Department of Microbiology, GMC, Ernakulam.

\section{Results}

A total number of 190 samples were received from 52 patients all over Kerala. All the samples tested were found to be negative for Nipah virus infection except the second sample received from the index case.

\section{Sample Analysis}

\begin{tabular}{|l|c|c|c|}
\hline S.No. & Sample & Total & Percentage (\%) \\
\hline 1 & Serum & 54 & 28.4 \\
\hline 2 & $\begin{array}{c}\text { Blood with } \\
\text { EDTA }\end{array}$ & 16 & 8.4 \\
\hline 3 & CSF & 10 & 5.2 \\
\hline 4 & Throat swab & 51 & 30 \\
\hline 5 & Urine & 57 & 26.84 \\
\hline 6 & $\begin{array}{c}\text { Endotracheal } \\
\text { aspirate }\end{array}$ & 2 & 1 \\
\hline & Total & 190 & 100 \\
\hline
\end{tabular}

2. Age wise distribution of suspected cases

\begin{tabular}{|l|c|c|}
\hline Age group & No. of cases & Percentage (\%) \\
\hline $0-10$ & 3 & 5.7 \\
\hline $11-20$ & 7 & 13.5 \\
\hline $21-30$ & 11 & 21.15 \\
\hline $31-40$ & 9 & 17.3 \\
\hline $41-50$ & 6 & 11.5 \\
\hline $51-60$ & 7 & 13.5 \\
\hline $61-70$ & 3 & 5.7 \\
\hline $71-80$ & 4 & 7.6 \\
\hline$>80$ & 2 & 3.8 \\
\hline Total & 52 & 100 \\
\hline
\end{tabular}


3. Gender distribution of suspected cases

\begin{tabular}{|l|c|c|}
\hline Gender & Number & Percentage (\%) \\
\hline Male & 27 & 51.92 \\
\hline Female & 25 & 48.08 \\
\hline Total & 52 & 100 \\
\hline
\end{tabular}

4. District wise distribution of samples received for Nipah virus detection

\begin{tabular}{|l|c|c|c|}
\hline S.No. & District & Number & Percentage (\%) \\
\hline 1. & Ernakulam & 75 & 39.5 \\
\hline 2. & Thrissur & 38 & 20 \\
\hline 3. & Idukki & 15 & 7.9 \\
\hline 4. & Malappuram & 12 & 6.3 \\
\hline 5. & Palakkad & 11 & 5.8 \\
\hline 6. & Trivandrum & 11 & 5.8 \\
\hline 7. & Alappuzha & 10 & 5.2 \\
\hline 8. & Kollam & 7 & 3.7 \\
\hline 9. & Kozhikode & 4 & 2.1 \\
\hline 10. & Kannur & 4 & 2.1 \\
\hline 11. & Kottayam & 3 & 1.6 \\
\hline & Total & 190 & 100 \\
\hline
\end{tabular}

5. Symptom wise distribution of suspected cases $(n=52)$

\begin{tabular}{|l|c|c|c|}
\hline S.No. & Symptoms & Number & $\begin{array}{c}\text { Percentage } \\
(\%)\end{array}$ \\
\hline 1. & $\begin{array}{c}\text { Respiratory symptoms } \\
\text { without } \\
\text { fever(Cough,Dyspnoea) }\end{array}$ & 40 & 76.92 \\
\hline 2. & Encephalitis & 19 & 36.5 \\
\hline 3. & $\begin{array}{c}\text { Fever,Myalgia,Respiratory } \\
\text { distress }\end{array}$ & 41 & 78.8 \\
\hline 4. & Fever+cough & 20 & 38.5 \\
\hline 5. & $\begin{array}{c}\text { Fever + vomiting+ neck } \\
\text { rigidity }\end{array}$ & 14 & 26.92 \\
\hline 6. & Fever + disorientation & 19 & 36.5 \\
\hline
\end{tabular}

\section{Discussion}

Out of the 190 samples received from 11 different districts in Kerala, maximum number of samples (39.5\%) were from Ernakulam (Central Kerala) where the index case was identified, followed by Thrissur, the neighboring district of Ernakulam $(20 \%)$. The increase in number of suspected cases at Ernakulam may be due to the fear and anxiety of the persons for getting Nipah virus infection since the index case was from Ernakulam district. Psychological factors play a role during an outbreak. Suspected cases were found to be more in the age group between 21-30 years $(21.15 \%)$ followed by the age group between 31-40 years $(17.3 \%)$.Of the suspected cases $52 \%$ were males and $48 \%$ were females. The male preponderance and the predominant age group between 21 to 30 years may be associated with people actively engaged more in outdoor activities.

Among the different types of samples received, $38 \%$ were blood samples followed by urine samples (30\%).While analyzing the symptoms, majority of the suspected cases had fever, myalgia and respiratory distress $(78.8 \%)$ followed by respiratory symptoms without fever such as cough and breathlessness without fever (76.92\%).19 suspected cases with encephalitis were admitted in different hospitals (36.5\%).

All the samples tested by real time -PCR were negative for Nipah virus infection. IgM ELISA was also negative for Nipah antibodies in all these cases. During the Nipah virus outbreak at Kozhikode district in Kerala in 2018, 17 deaths were reported in laboratory confirmed cases. The index case reported from Ernakulam district in Kerala in 2019, survived. The mortality rate was nil during the present outbreak.

Nipah virus is an emerging zoonotic virus causing seasonal outbreaks of encephalitis in Bangladesh with $>75 \%$ mortality. Fruit bats are the reservoirs of infection. A study by Epstein, Anthony, Islam et al from Bangladesh have reported that $\mathrm{NiV}$ RNA was detected in $3.8 \%$ of bats. Seroprevalence among bats was $20-56 \%$.

First outbreak of Nipah virus infection occurred in Kampung Sungai Nipah, Malaysia in 1998.Later outbreaks occurred in West Bengal in 2001 and Bangladesh in 2004.Nipah virus outbreaks with person toperson transmission have occurred repeatedly in rural Bangladesh. Chada et al have reported a nosocomial outbreak involving more than 60 people in a hospital at Siliguri, West Bengal in 2001.

In 2014, an outbreak of Nipah virus occurred in two villages of Philippines. Of the 17 cases, 11 had acute encephalitis, one meningitis and five had an influenza like illness. Laboratory testing of these patients revealed neutralizing antibodies and IgM antibodies against Nipah virus. 
In January 2017,Nipah virus was listed as one of the three viruses causing priority diseases along with Lassa virus and Middle East Respiratory Syndrome Corona virus (MERS-COV) by WHO which require investment in research and development for diagnostics, prevention and treatment.

Arankalle et al reported a smaller nosocomial outbreak which occurred in West Bengal in 2001.In the outbreak in Faridpur, Bangladesh in 2004, the nosocomial transmission was demonstrated by the detection of Nipah virus RNA on hospital surfaces.

The Nipah virus outbreak in Kerala, India started with direct contact of humans with fruit bats and consequent nosocomial infection. Environmental factors play a vital role in the emergence of zoonotic diseases in humans. Climatic changes, deforestation, urbanization, destruction of animal habitats cause starvation and low immunity in bats, increasing viral loads in their body which is excreted in the secretion of bats, thereby infecting the fruits, animals and humans who come in contact with them. The repeated outbreaks may be due to low health care system. The epidemiological pattern of Nipah virus in India, makes it potential for urban outbreaks to occur in the near future.

The first outbreak from Kerala occurred in May 2018 and the mortality rate was quite high. The second outbreak started by the end of May 2019. Because of the preparedness, strict isolation policies and effective surveillance, it was stopped at the index case level. Immediately after getting laboratory confirmation from $\mathrm{NiV}$, Pune for the index case, Isolation ward was set up in all tertiary care centres. Awareness classes were given to all categories of health care workers. Training was given for donning and doffing of personal protective equipment (PPE), Triple packing and details of transportation of samples. To avoid transportation difficulties and delay in getting reports from NIV Pune, Nipah POC testing facility was started in the Department of Microbiology and samples received from all over
Kerala were tested immediately without delay. Coordination of rapid diagnostic testing was implemented. Training on lab testing was given by the experts from NIV, Pune. Health education to all categories of people was given by the Health Services. Effective containment of Nipah virus infection was made possible by the efficient health care system in Kerala.

\section{Conclusion}

Nipah POC Testing Facility established at the Department of Microbiology GMC, Ernakulam during outbreak 2019 was very useful and all the districts were benefitted by the services of the POC testing facility at Ernakulam. The Kerala Health Services played a key role in transportation of samples from different district to the POC testing centre. The samples reached POC testing centre in time and made available for the rapid diagnostic testing. Issue of results immediately after testing significantly reduced the anxiety of patients as well as health care providers. Coordination and Cooperation of the entire health care system helped in the effective management of Nipah outbreak 2019 in Kerala.

\section{Acknowledgement}

1) We are extremely thankful to Dr. D.T. Maurya, Director NIV, Pune for his timely help and guidance during the outbreak.

2) We are grateful to Dr. Rima Sahay, Dr. Anita Shete, Mrs. Triparna Majumdar, faculties and technical experts from NIV Pune, who have done the tests during the initial phase and given training on laboratory testing to all faculties and lab technicians of our department and other Government Medical colleges.

3) We thank Dr. Anu Kumar, Director NIV, Alappuzha for all the help extended while setting up of a POC testing facility at the Department of Microbiology at GMC, Ernakulam. 
4) We extend our gratitude to Dr. Pragya NIV Pune for her support and guidance from the very beginning.

5) We would like to thank Dr. Ullas and Dr. Deepak for their technical support and all the help extended by them while doing the laboratory testing.

\section{Financial Support and Sponsorship: Nil Conflicts of Interest: Nil}

\section{References}

1. Aiswarya $S$ Ambat et al. Nipah virus: A review on epidemiological characteristics and outbreaks to inform public health decision making. Journal of Infection and Public Health (2019):12: 634-639

2. H. Donaldson D. Lucey et al. Enhancing preparation for large Nipah outbreaks beyond Bangladesh: Preventing a tragedy like Ebola in West Africa. International Journal of Infectious diseases (2018):: 72 69-72

3. N. Homaira, M. Rahman et al .Evidence of person -person transmission of Nipah virus through casual contact International Journal of Infectious Diseases(2008): 5 :248

4. JH Epstein, SJ Anthont et al . Nipah virus ecology and infection dynamics in its bat reservoir, Pteropusmedius, in Bangladesh; International Journal of Infectious Diseases(2016):11:056

5. S. Ariyari, N. Vijayan et al. The first ever Nipah virus outbreak and the best possible response by a tiny state of India; International Journal of Infectious Diseases (2018):11:0567
6. Michael K,Paul A et al .The emergence of Nipahvirus, a highly pathogenic paramyxovirus; Journal of Clinical Virology (2008):43:396-400

7. ICDDRB. Nipah encephalitis outbreak over a wide area of Banladesh. Hlth Sci Bull 2004:2:7-11

8. WHO. Nipah virus outbreaks in Bangladesh. January -April 2004. Wklyb Epidemiol Rec 2004:17:168-71

9. Chadha MS. Comer JA et al .Nipah virus associated encephalitis outbreak. Siliguri, India. Emerging Infectious Diseases 2006: 12:235-40

10. Harit AK, Ichhpujani et al .Nipah virus outbreaks in Siliguri, West Bengal ,India in 2001 .Indian Journal of Medical Research 2006:123:553-60

11. Gurley ES, Montgomery JM et al.Person to person transmission of Nipah virus in a Bangladeshi community .Emerging Infectious diseases 2007:13:1031-7

12. Gurley ES, Montgomery JM et al.Risk of nosocomial transmission of Nipah virus in a Bangladesh hospital .Infection control Hosp Epidemiol 2007:28:740-2

13. Bowden TA, Aricescu AR et al.Structural basis of Nipah and Hendra virus attachment to their cell surface receptor ephrin b2.at Struct Mol Biol 2008

14. Guillaume V. Lefeuvre A et al .Specific detection of Nipah virus using real time RT -PCR.J of Viorol Methods 2004: 120:229-37. 